\title{
A four-step scalable formal synthesis of ningalin C
}

\author{
Velayudham Ramadoss, ${ }^{a}$ Pradip D. Nahide, ${ }^{a}$ Kevin A. Juárez-Ornelas, ${ }^{a}$ \\ Marvin Rentería-Gómez, ${ }^{a}$ David Cruz-Cruz, ${ }^{a}$ Eduardo Peña-Cabrera, ${ }^{a}$ \\ Rafael Ortiz-Alvarado ${ }^{b}$ and César R. Solorio-Alvarado ${ }^{a *}$
}

${ }^{a}$ Departamento de Química, División de Ciencias Naturales y Exactas, Campus Guanajuato, Universidad de Guanajuato, Cerro de la Venada S/N, 36040, Guanajuato, Gto., México

${ }^{b}$ Facultad de Químico Farmacobiología, Universidad Michoacana de San Nicolás de Hidalgo, Tzintzuntzan 173, Colonia Matamoros, 58240, Morelia, Michoacán, México

E-mail:csolorio@ugto.mx

DOI: http://dx.doi.org/10.3998/ark.5550190.p009.631

\begin{abstract}
A practical, concise and scalable synthesis of a key intermediate in the preparation of the alkaloid ningalin C was developed over four steps in $29 \%$ overall yield. The procedure involves three commercially available starting materials and uses the chemistry of squaric esters. In view of the relevance of scalability in recent times, herein is highlighted the importance of the developed strategy, allowing the preparation of close to $300 \mathrm{mg}$ of the key quinone.
\end{abstract}

Keywords: Ningalin C, formal synthesis, squaric esters

\section{Introduction}

Isolated in 1997 by Fenical and Kang ${ }^{1}$ from Australian tunicates in the Ningaloo reef, the marine alkaloid ningalin $\mathrm{C} \mathbf{1}$ is one of the most complex metabolites described from this sponge (Figure $1)$.<smiles>O=C1C(c2ccc(O)c(O)c2)=C2C(=C(c3ccc(O)c(O)c3)C(=O)N2CCc2ccc(O)c(O)c2)c2cc(O)c(O)cc21</smiles>

Figure 1. Structure of ningalin C. 
Ningalin $\mathrm{C}$ is composed of a highly functionalized benzo[e]indole-2,5(3H)-dione core, substituted with catechol rings in the 1 and 4 positions and a 3,4-dihydroxyphenethyl group directly attached to the nitrogen. Several structurally related alkaloids can be identified as close family members, for example polycitrins, ${ }^{2-4}$ storniamides ${ }^{5,6}$ and ningalins A, B and $\mathrm{D}^{1}$ (Figure 2).<smiles>O=c1oc2cc(O)c(O)cc2c2c1[nH]c1c(=O)oc3cc(O)c(O)cc3c12</smiles>

Ningalin A<smiles>O=c1oc2cc(O)c(O)cc2c2c(-c3ccc(O)c(O)c3)cn(CCc3ccc(O)c(O)c3)c12</smiles>

Ningalin B<smiles>O=C1C(=O)c2cc(O)c(O)cc2-c2c3n(CCc4ccc(O)c(O)c4)c(c2=C1c1ccc(O)c(O)c1)=C(c1ccc(O)c(O)c1)C(=O)c1cc(O)c(O)cc1-3</smiles>

Ningalin D<smiles>O=C1C(c2cc(Br)c(O)c(Br)c2)=C(c2cc(Br)c(O)c(Br)c2)C(=O)N1CCc1ccc(O)cc1</smiles>

$R=-H$, polycitrin $A$ $\mathrm{R}=-\mathrm{Me}$, polycitrin $\mathrm{B}$<smiles>[R]c1cc(/C=C/NC(=O)c2c(C(=O)N/C=C/c3cc([R2])c(O)c(O)c3)c(-c3cc(O)c(O)c(O)c3)c(C(=O)N/C=C/c3ccc(O)c([R])c3)n2CCc2ccc(O)cc2)ccc1O</smiles>

$\mathrm{R}=\mathrm{R}^{1}=-\mathrm{H}, \mathrm{R}^{2}=-\mathrm{OH}$, storniamide $\mathrm{A}$ $\mathrm{R}=\mathrm{R}^{2}=-\mathrm{OH}, \mathrm{R}^{1}=-\mathrm{H}$, storniamide $\mathrm{B}$ $R=R^{1}=-O H, R^{2}=-H$, storniamide $C$ $\mathrm{R}=\mathrm{R}^{1}=\mathrm{R}^{2}=-\mathrm{OH}$, storniamide $\mathrm{D}$

Figure 2. Structurally related family members of ningalin C.

This class of compound becomes an important molecular target by the fact they apparently contain condensed DOPA [(2-amino-3-(3,4-dihydroxyphenyl)propanoic acid] subunits in their proposed biosynthetic pathway. ${ }^{7}$ Additionally the substituted pyrrole nucleus of the ningalin $\mathrm{C}$, as maleimide derivatives, have been broadly described as modulators in the overexpression of P-gp. ${ }^{8}$ The point is highly relevant since P-gp is one of the main mechanisms used by different cells in 
several cancer types. This glycoprotein excretes the anticancer drug administered as part of the treatment out of the cell, resulting in resistance ${ }^{9,10}$ by these cells to different drugs (MDR). ${ }^{11}$

The synthesis of ningalin $\mathrm{C}$ has been carried out only twice to date. The first, described by Steglich, ${ }^{12}$ required seven steps. The procedure used consecutive oxidations on the 3-(3,4dihydroxyphenyl)-2-oxopropanoic acid. In this route a pentasubstituted pyrrole ring is the key intermediate (Scheme 1a). The second synthesis was also completed in seven steps by Ruchirawat. ${ }^{13}$ In his procedure a tetrasubstituted 1,4-naphthoquinone was prepared as a key compound in the methodology (Scheme 1b).
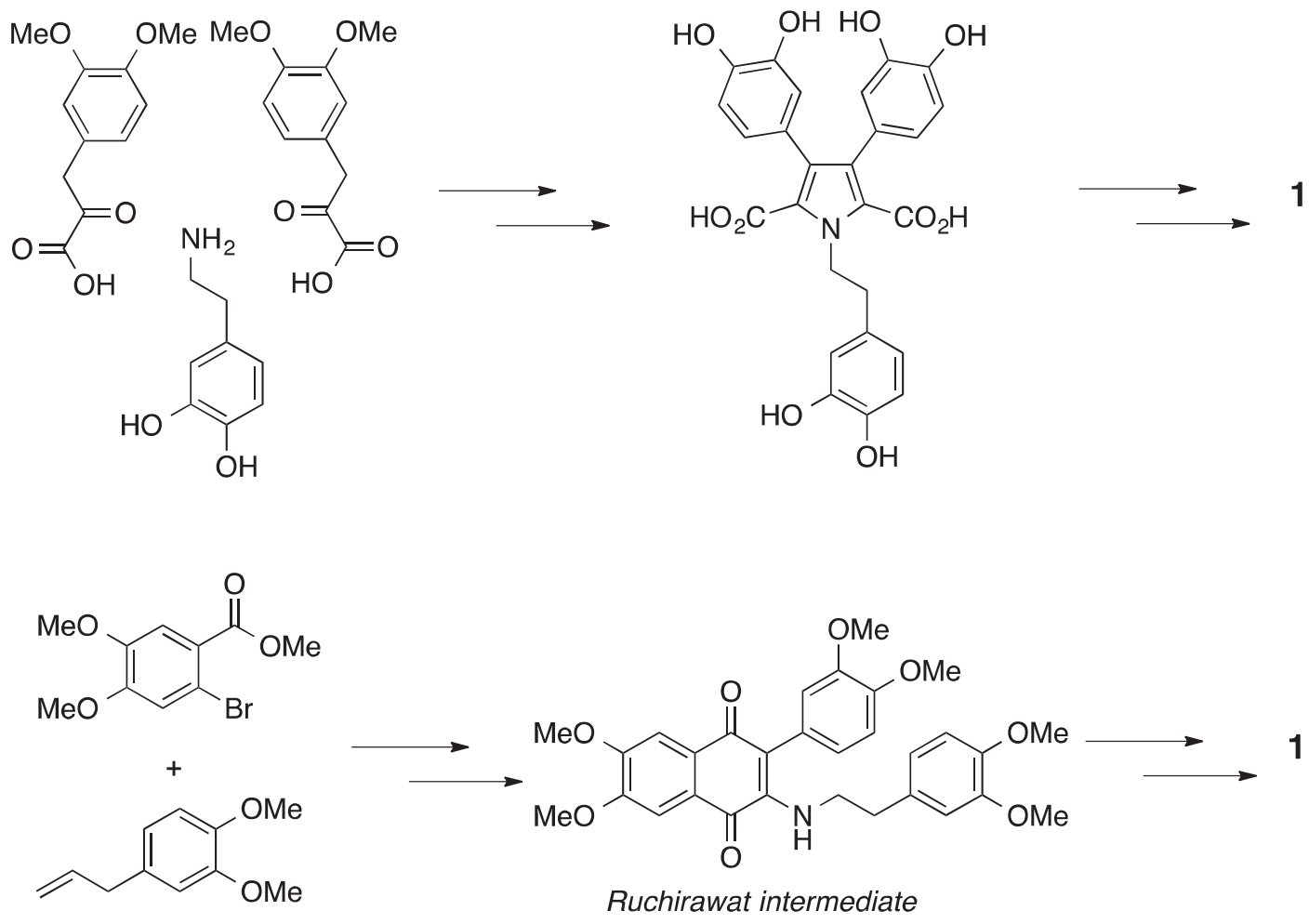

Scheme 1. Described total synthesis of ningalin C. a) Steglich procedure and b) Ruchirawat strategy.

Even though both procedures successfully achieved the completion of the total synthesis of ningalin $\mathrm{C}$, they lack scalability. ${ }^{14}$ This is a relevant aspect concerning to the total synthesis, since a considerably large amount of starting materials are required to get the final compound, of which sufficient quantities of it would be necessary in order to carry out biological activity tests. Additionally the redox fluctuation (e.g. reduction-oxidation-reduction) $)^{15}$ is also an important deterrent present in both strategies, which diminish the atom economy ${ }^{16}$ in the global process. 


\section{Results and Discussion}

Considering the relevance of ningalin $\mathrm{C}$ and the main inconveniences in the Steglich and Ruchirawat syntheses, we decide to start our own synthetic approach toward an efficient formal synthesis of such alkaloid. We considered the chemistry of squaric esters as good strategy in order to synthesize in a short and scalable route the key quinone intermediate according to the Ruchirawat ${ }^{13}$ total synthesis.

Thus the formal retro-synthesis of ningalin $\mathrm{C}$ was envisioned as follows (Scheme 2).

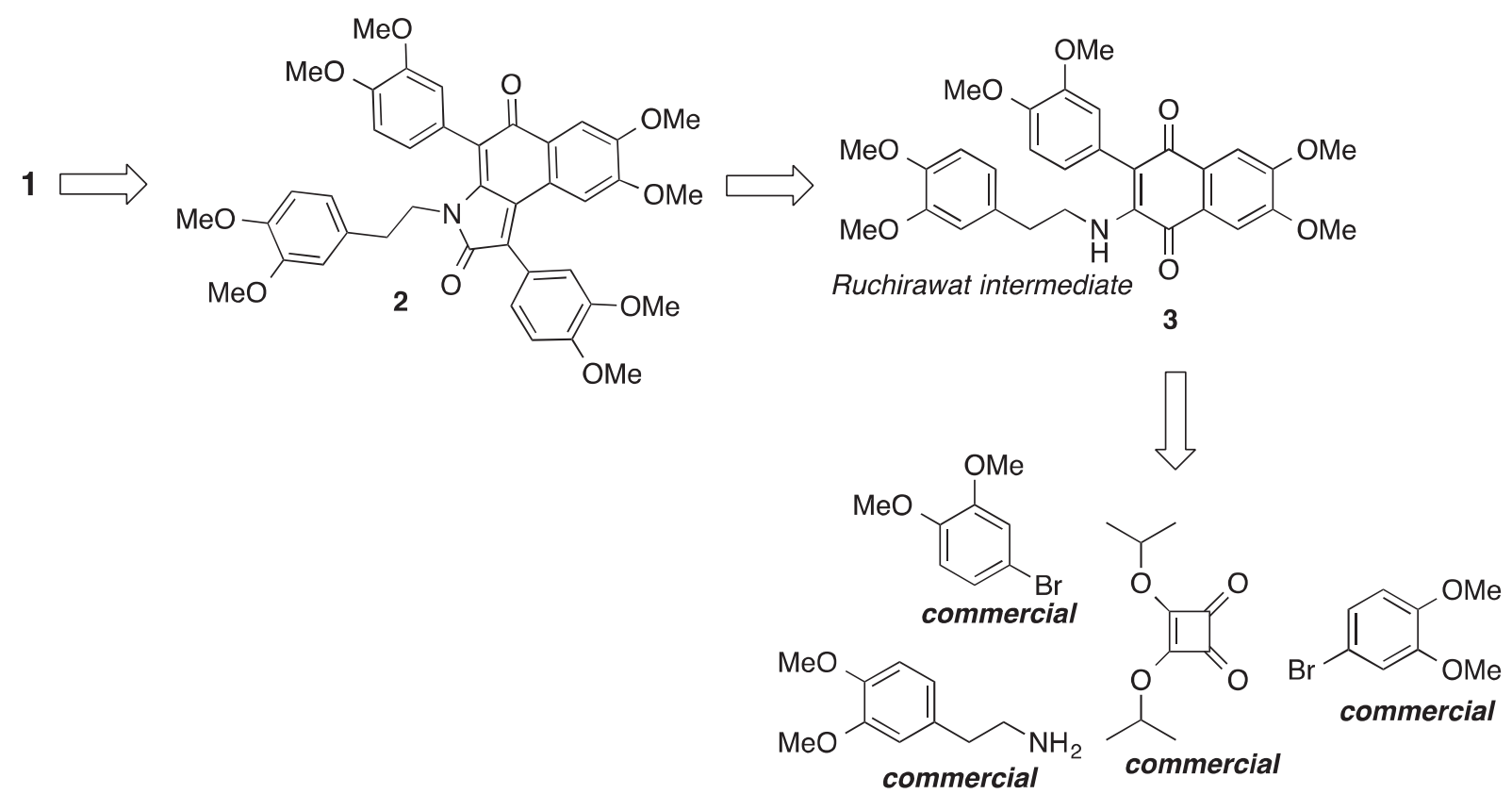

Scheme 2. Squaric ester-based retrosynthetic analysis of the ningalin C.

The analysis shows the use of only three commercially available starting materials, which will generate the Ruchirawat quinone intermediate 3. The 1,2-addition of the methyl 2-(3,4dimethoxyphenyl)acetate anion to the more reactive carbonyl of the naphthoquinone gives 2 which finally yields 1 by hydroxyl group deprotection. ${ }^{13}$

Therefore we started our synthesis according to the following route (Scheme 3). 
<smiles>CC(C)Oc1c(OC(C)C)c(=O)c1=O</smiles>

1)<smiles>COc1ccc(Cl)cc1OCC(=O)O</smiles>

2) $\mathrm{NH}_{4} \mathrm{Cl}_{\text {(sat) }}$

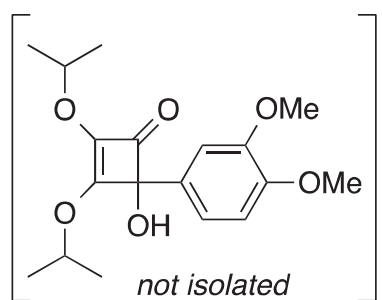

7

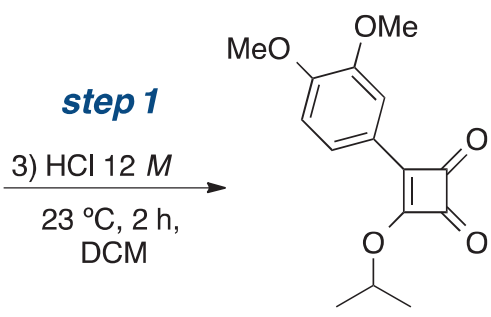

6, $55 \%$ (1.45 g prepared)

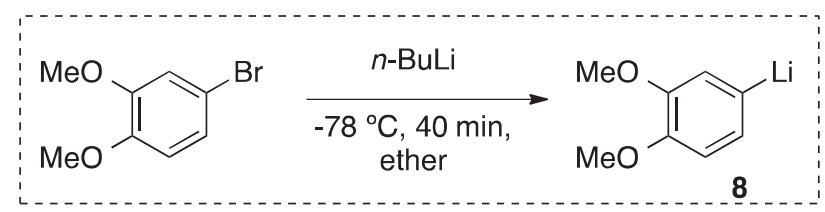<smiles>COc1ccc(CCN)cc1OC</smiles>

$\mathrm{MeOH}, 16 \mathrm{~h}, 40^{\circ} \mathrm{C}$ step 4 (900 mg prepared)<smiles>COc1ccc(C2=C(OC(C)C)C(=O)c3cc(OC)c(OC)cc3C2=O)cc1OC</smiles>

4, >99\%

Ref. 13

4)<smiles>COc1ccc(Cl)cc1OC</smiles>

5) $\mathrm{NH}_{4} \mathrm{Cl}_{\text {(sat) }}$ neat

$180^{\circ} \mathrm{C}$

step 3

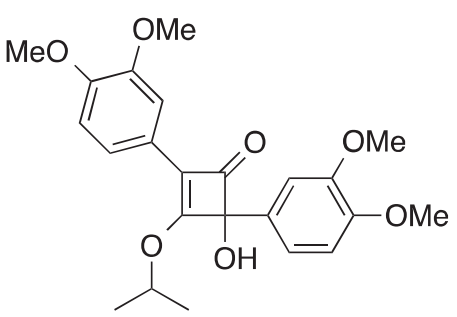

5, $93 \%$

(1.4 $\mathrm{g}$ prepared)<smiles>COc1ccc(CCNC2=C(c3ccc(OC)c(OC)c3)C(=O)c3cc(OC)c(OC)cc3C2=O)cc1</smiles>

Scheme 3. Squaric ester-based formal synthesis of ningalin C.

Our synthesis started with the in situ generation of (3,4-dimethoxyphenyl)lithium 8 by metalhalogen exchange in the commercially available bromoveratrole at low temperature. The 1,2addition of $\mathbf{8}$ to diisopropoxysquarate, which is also commercially available, produces $\mathbf{7}$ after aqueous treatment. A solvent change for the acid treatment of 7 with ten drops of $12 \mathrm{M} \mathrm{HCl}$ yields squaric ester $\mathbf{6}$ in a moderate 55\% yield on a gram scale. This two-reaction pot is the first step in 
our strategy efficiently carried out considering that $55 \%$ represents a $74 \%$ average yield by each reaction.

A new addition of $\mathbf{8}$ to the more reactive carbonyl in $\mathbf{6}$ give rise to $\mathbf{5}$ after neutralization, in excellent $93 \%$ yield. This second step holds true also in gram scale.

The solvent-free heating of 5 at $180{ }^{\circ} \mathrm{C}$ promotes the electrocyclic [4+2] ring expansion to get 4 in nearly quantitative yield and notably in gram scale. For this third step, no chromatographic purification was necessary.

Finally, the commercially available homoveratrylamine undergoes a Michael additionelimination reaction on $\mathbf{4}$ to yield the desired Ruchirawat quinone 3 in a modest $57 \%$ yield.

Regarding the ${ }^{1} \mathrm{H}$ spectrum of $\mathbf{3}$, some representative signals like a triplet at 2.58 and doublet-ofdoublets at 2.96 confirm the benzylic and homobenzylic methylenes from the amine addition. Five singlets between 3.82-4.00 ppm represents the six -OMe present in the molecule. The aromatic signals integrate perfectly for the corresponding total amount of hydrogens in this region. Regarding the ${ }^{13} \mathrm{C}$ spectrum some characteristic peaks like 35.9 and $45.7 \mathrm{ppm}$ correspond to the benzylic and homobenzylic carbons attached to the phenetyl group. Six peaks between 55.9-56.5 correspond to the -OMe groups. Seven signals between 144.5-154.5 ppm confirms the presence of one vinylogous (C-N) and six (C-OMe) bonds. Two carbonyls at 182.1 and 182.4 are observed and finally thirteen carbons between 107.8-130.6 complete the total amount of carbons. The previously described chemical shifts in the Ruchirawat synthesis ${ }^{13}$ perfectly match with our spectrocopical data of 3. This fourth step concludes our formal synthesis of marine alkaloid ningalin $\mathrm{C} 1$ (Scheme 3), the completion of the total synthesis is at the moment out of the project and is no described in this manuscript.

\section{Conclusions}

In summary: we have been able to complete successfully a formal synthesis of the naturally occurring compound ningalin C. Some important points are worthy of highlight in this described strategy:

1. Only three starting materials were used for the complete synthetic procedure. All of them are commercially available. This is a remarkable advantage since the synthesis can start any time.

2. The synthetic methodology is short, only four steps are required.

3. The procedure entails easy and well-known reactions.

4. The general protocol is a high-yielding strategy.

5. This process was developed in gram scale on the first three steps. And the last one in close to $300 \mathrm{mg}$ scale. Which makes it a scalable process regarding the last synthesis, ${ }^{13}$ which yields no more than $75 \mathrm{mg}$ of the key quinone.

6. In our strategy there is no redox fluctuation (i.e. reduction-oxidation-reduction). All of the steps gave rise to more oxidized compounds in each reaction. 


\section{Experimental Section}

General. ${ }^{1} \mathrm{H}$ NMR spectra were recorded on a Bruker $500 \mathrm{MHz}$ in deuterated chloroform $\left(\mathrm{CDCl}_{3}\right)$ with either tetramethylsilane (TMS), $(0.0 \mathrm{ppm})$ or chloroform $(7.26 \mathrm{ppm})$ as internal reference unless otherwise indicated. Acquisition temperature was $298 \mathrm{~K}$ for all NMR experiments. Data are reported in the following order: chemical shift in ppm $(\delta)$, multiplicities (br (broadened)), s (singlet), d (doublet), t (triplet), q(quartet), sex (sextet), hep (heptet), m (multiplet), exch (exchangeable), app (apparent), coupling constants, J, are reported $(\mathrm{Hz})$, and integration. Infrared spectra were recorded on a Perkin-Elmer FTRI 1600 series spectrophotometer. Peaks are reported $\left(\mathrm{cm}^{-1}\right)$ with the following relative intensities: s (strong 67-100\%), m (medium 40-67 \%), and w (weak 20-40\%). Analytical thin-layer chromatography was performed on Merck silica gel plates with F-254 indicator. Visualization was accomplished by UV-light, iodine or $p$-anisaldehyde solution. THF was dried over sodium and stored over activated $4 \AA$ molecular sieves. All reactions were performed under a dry $\mathrm{N}_{2}$ atmosphere in oven- or flame-dried glassware. High Resolution Mass Spectra (HRMS) were obtained on a Bruker microTOF fitted with an ESI.

\section{3-(3,4-Dimethoxyphenyl)-4-isopropoxycyclobut-3-ene-1,2-dione (6)}

4-(3,4-Dimethoxyphenyl)-4-hydroxy-2,3-diisopropoxycyclobut-2-en-1-one (7). In a twonecked $250 \mathrm{~mL}$ round bottom flask containing a dry ether $(10 \mathrm{~mL})$ solution of 4-bromoveratrole (3.288 g, $15.151 \mathrm{mmol}, 1.50$ equiv) was cooled to $-78^{\circ} \mathrm{C}$ under $\mathrm{N}_{2}$ atmosphere. $n$-BuLi $(8.33 \mathrm{~mL}$, $16.665 \mathrm{mmol}, 1.65$ equiv) was added via syringe. After $30 \mathrm{~min}$, diisopropoxysquarate $(2.000 \mathrm{~g}$, $10.101 \mathrm{mmol}, 1.00$ equiv) dissolved in dry THF $(5 \mathrm{~mL})$ was added via syringe. After $30 \mathrm{~min}$, the cooling bath was removed, allowing to reach room temperature. $\mathrm{A} \mathrm{NH}_{4} \mathrm{Cl}_{\text {(sat) }}$ solution $(100 \mathrm{~mL})$ was added and stirred for $1 \mathrm{~h}$. The reaction mixture was extracted with EtOAc $(3 \times 15 \mathrm{~mL})$, dried over $\mathrm{Na}_{2} \mathrm{SO}_{4}$ and concentrated in vacuo to give a yellowish oil.

Synthesis of 6. Immediately and without inert atmosphere, the oil was dissolved in DCM (10 mL) followed by addition of 10 drops of $\mathrm{HCl} 12 \mathrm{M}$. The reaction is stirred along $40 \mathrm{~min}$. The reaction mixture was neutralized using a $\mathrm{NaHCO}_{3 \text { (sat) }}$ solution $(10 \mathrm{~mL})$. Extractive work up using DCM (2 $\times 15 \mathrm{~mL}$ ), drying over $\mathrm{Na}_{2} \mathrm{SO}_{4}$ and concentration in vacuo gave the crude reaction product, which was purified by column chromatography ( $20 \%$ AcOEt/hexane) to provide 6 as a red powder $(1.450$ g, 55\%). $\mathrm{R}_{f} 0.3$ (10\% AcOEt/hexane). mp 131-133 ${ }^{\circ} \mathrm{C}$. IR $\left(\mathrm{cm}^{-1}\right)=2985(\mathrm{w}), 2940(\mathrm{w}), 2045(\mathrm{w})$, 1776 (s), 1589 (s), 965 (w). ${ }^{1} \mathrm{H}$ NMR ( $\left.\mathrm{CDCl}_{3}, 500 \mathrm{MHz}\right) \delta 7.67$ (dd, $J$ 8.4, $\left.2.0 \mathrm{~Hz}, 1 \mathrm{H}\right), 7.60$ (d, $J$ $2.0 \mathrm{~Hz}, 1 \mathrm{H}), 6.97$ (d, J 8.4 Hz, 1H), 5.58 (hept, J 6.5 Hz, 1H), 3.95 (s, 3H), 3.94 (s, 3H), 1.55 (d, $J 5.0 \mathrm{~Hz}, 6 \mathrm{H}) .{ }^{13} \mathrm{C} \mathrm{NMR}\left(\mathrm{CDCl}_{3}, 126 \mathrm{MHz}\right.$,) $\delta$ 193.2, 193.1, 191.6, 173.9, 153.0, 149.3, 122.5, 121.1, 111.3, 109.9, 79.8, 56.2, 56.1, 23.1. HRMS (ESI $\left.{ }^{+}\right)$: calcd. for $\mathrm{C}_{15} \mathrm{H}_{17} \mathrm{O}_{5}[\mathrm{M}+\mathrm{H}]: 277.1076$, found 277.1109 .

2,4-Bis-(3,4-dimethoxyphenyl)-4-hydroxy-3-isopropoxycyclobut-2-en-1-one (5). A twonecked $250 \mathrm{~mL}$ round bottom flask containing a dry ether $(10 \mathrm{~mL})$ solution of 4-bromoveratrole (1.179 g, $5.435 \mathrm{mmol}, 1.50$ equiv) under $\mathrm{N}_{2}$ atmosphere was cooled to $-78{ }^{\circ} \mathrm{C} . n$-BuLi $(2.98 \mathrm{~mL}$, $5.978 \mathrm{mmol}, 1.65$ equiv) was added via syringe. After $30 \mathrm{~min}, 3-(3,4-d i m e t h o x y p h e n y l)-4-$ 
isopropoxycyclobut-3-ene-1,2-dione (6) (1.000 g, $3.623 \mathrm{mmol}, 1.00$ equiv) in dry THF (5 mL) was added via syringe. After $30 \mathrm{~min}$, the cooling bath was removed, allowing to reach room temperature. Saturated aqueous $\mathrm{NH}_{4} \mathrm{Cl}(50 \mathrm{~mL})$ was added and the mixture was stirred for $1 \mathrm{~h}$. The reaction mixture was extracted with EtOAc $(3 \times 15 \mathrm{~mL})$, dried over $\mathrm{Na}_{2} \mathrm{SO}_{4}$ and concentrated in vacuo to give a yellowish oil. The crude product was purified by column chromatography ( $40 \%$ AcOEt/hexane) to give a pure yellow solid product (1.40 g, 93\%) $\mathrm{R}_{f} 0.3(20 \% \mathrm{AcOEt} /$ hexane $) . \mathrm{Mp}$ 60-62 ${ }^{\circ} \mathrm{C}$. IR: $3436(\mathrm{~m}), 2936(\mathrm{~m}), 2837(\mathrm{w}), 1750(\mathrm{~m}), 1139$ (s), $904(\mathrm{w}) \mathrm{cm}^{-1} .{ }^{1} \mathrm{H}$ NMR $\left(\mathrm{CDCl}_{3}\right.$, $500 \mathrm{MHz}): \delta 7.38-7.33(\mathrm{~m}, 2 \mathrm{H}), 7.11(\mathrm{~d}, J 1.9 \mathrm{~Hz}, 1 \mathrm{H}), 7.02(\mathrm{dd}, J 8.3,2.0 \mathrm{~Hz}, 1 \mathrm{H}), 6.86(\mathrm{t}, J$ 8.0, 2H), 4.83 (hept, $J 6.1 \mathrm{~Hz}, 1 \mathrm{H}), 3.90$ (s, 6H), 3.87 (s, 6H), 1.47 (t, J 6.1 Hz, 3H), 1.14 (d, J 6.1 $\mathrm{Hz}, 3 \mathrm{H}) .{ }^{13} \mathrm{C} \mathrm{NMR}\left(\mathrm{CDCl}_{3}, 26 \mathrm{MHz}\right): 187.6,178.3,149.5,149.24,149.22,149.1,129.5,126.4$, $121.9,120.4,118.2,111.4,111.3,110.2,109.1,93.9,79.1,56.2,56.1,56.07,56.06,23.2,22.9$. HRMS (ESI+) calcd. for $\mathrm{C}_{23} \mathrm{H}_{26} \mathrm{O}_{7}[\mathrm{M}+\mathrm{H}]: 415.1757$, found 415.1792 .

2-(3,4-Dimethoxyphenyl)-3-isopropoxy-6,7-dimethoxynaphthalene-1,4-dione (4). In a $25 \mathrm{~mL}$ flask, 2,4-bis-(3,4-dimethoxyphenyl)-4-hydroxy-3-isopropoxycyclobut-2-en-1-one (5) (1.000 g, $2.415 \mathrm{mmol}$ ) was heated at $180{ }^{\circ} \mathrm{C}$ for $1 \mathrm{~h}$. After cooling, the crude material was dissolved in DCM and hexane was added to precipitate the pure orange compound $(0.900 \mathrm{~g},>99 \%) . \mathrm{R}_{f} 0.3(20 \%$ AcOEt/hexane). mp 252-255 ${ }^{\circ} \mathrm{C}$. IR $\left(\mathrm{cm}^{-1}\right)=2937(\mathrm{~m}), 2836(\mathrm{w}), 1659(\mathrm{~s}), 1266$ (s), 1140 (s). ${ }^{1} \mathrm{H}$ NMR $\left(\mathrm{CDCl}_{3}, 500 \mathrm{MHz}\right): \delta 7.56(\mathrm{~d}, J 9.7 \mathrm{~Hz}, 2 \mathrm{H}), 7.02-6.97(\mathrm{~m}, 2 \mathrm{H}) .6 .96-6.91(\mathrm{~m}, 1 \mathrm{H}), 4.63$ (hept, J 6.1 Hz, 1H), 4.04 (s, 3H), $4.03(\mathrm{~s}, 3 \mathrm{H}), 3.94(\mathrm{~s}, 3 \mathrm{H}), 3.90(\mathrm{~s}, 3 \mathrm{H}), 1.15$ (d, J 6.1 Hz, 6H).

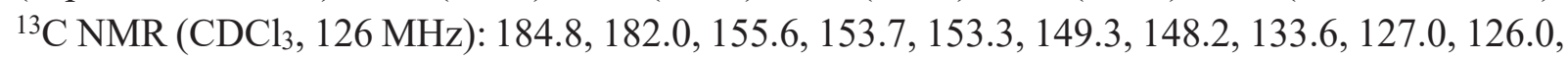
124.08, 123.6, 114.2, 108.3, 107.7, 76.7, 56.64, 56.6, 56.2, 56.0, 55.9, 22.8. HRMS (ESI ${ }^{+}$) calcd. for $\mathrm{C}_{23} \mathrm{H}_{25} \mathrm{O}_{7}[\mathrm{M}+\mathrm{H}]:$ 413.1601, found 413.1641.

\section{2-((3,4-Dimethoxyphenethyl)amino)-3-(3,4-dimethoxyphenyl)-6,7-dimethoxynaphthalene-}

1,4-dione (3). 3,4-Dimethoxyphenethylamine (1.02 mL, $6.067 \mathrm{mmol}, 5.00$ equiv) in $\mathrm{MeOH}(1$ $\mathrm{mL}$ ) was added to a solution of 2-(3,4-dimethoxyphenyl)-3-isopropoxy-6,7dimethoxynaphthalene-1,4-dione ( $0.500 \mathrm{~g}, 1.213 \mathrm{mmol}, 1.00$ equiv) in $\mathrm{MeOH}(5 \mathrm{~mL})$ contained in a $25 \mathrm{~mL}$ round-bottomed flask. The reaction mixture was heated at $40^{\circ} \mathrm{C}$ for $16 \mathrm{~h}$, after which the reaction crude was filtered off. The violet solid so obtained was washed with cold EtOH and purified by column chromatography (50\% AcOEt/hexane) to yield the pure quinone (3) $(0.283 \mathrm{~g}$, 57\%) $\mathrm{R}_{f} 0.3$ (50\% AcOEt/hexane). Mp 286-288 ${ }^{\circ} \mathrm{C}$. IR: 3341 (s), 3006 (s), 2934 (m), 2870 (w), 1518 (s), 1025 (s), 946 (w) (cm $\left.{ }^{-1}\right) .{ }^{1} \mathrm{H} \mathrm{NMR}\left(\mathrm{CDCl}_{3}, 500 \mathrm{MHz}\right): \delta 7.57$ (s, 1H), 7.47 (s, 1H), 6.91 $(\mathrm{d}, J 8.7 \mathrm{~Hz}, 1 \mathrm{H}), 6.86(\mathrm{~s}, 1 \mathrm{H}), 6.84(\mathrm{~d}, J 8.7 \mathrm{~Hz}, 2 \mathrm{H}), 6.76(\mathrm{~d}, J 8.1 \mathrm{~Hz}, 1 \mathrm{H}), 6.56(\mathrm{dd}, J 8.1,1.6$ $\mathrm{Hz}, 1 \mathrm{H}), 6.46(\mathrm{~d}, J 1.6 \mathrm{~Hz}, 1 \mathrm{H}), 6.05(\mathrm{t}, J 5.8 \mathrm{~Hz}, 1 \mathrm{H}), 4.00(\mathrm{~s}, 6 \mathrm{H}), 3.91(\mathrm{~s}, 3 \mathrm{H}), 3.88(\mathrm{~s}, 3 \mathrm{H}), 3.83$ $(\mathrm{s}, 3 \mathrm{H}), 3.82(\mathrm{~s}, 3 \mathrm{H}), 2.96(\mathrm{dd}, J 6.3 \mathrm{~Hz}, 2 \mathrm{H}), 2.58(\mathrm{t}, J 3.4 \mathrm{~Hz}, 2 \mathrm{H}) \cdot{ }^{13} \mathrm{C} \mathrm{NMR}\left(\mathrm{CDCl}_{3}, 298.13 \mathrm{~K}\right.$, $126 \mathrm{MHz})$ : 182.4, 182.1, 154.5, 152.0, 149.2, 148.5, 148.4, 148.0, 144.5, 130.6, 128.9, 127.0, $124.3,123.9,120.7,114.8,114.2,111.8,111.6,110.7,108.5,107.8,56.5,56.4,56.0,55.98,55.97$, 55.9, 45.7, 35.9. HRMS (ESI ${ }^{+}$) calcd. for $\mathrm{C}_{30} \mathrm{H}_{32} \mathrm{NO}_{8}[\mathrm{M}+\mathrm{H}]: 534.2128$, found 534.2115. 


\section{Acknowledgements}

We gratefully thank FOMIX (CONACyT-CONCyTEG) GTO-2012-C03-194610 for financial support. We acknowledge the facilities from the DCNyE, Chemistry Department, Guanajuato University in the National Laboratory UG-CONACyT (LACAPFEM) for full characterization. We thanks to CONACyT for fellowships to V. Ramadoss and P.Nahide.

\section{References and Notes}

1. Fenical, W.; Kang, H. J. Org. Chem. 1997, 62, 3254. http://pubs.acs.org/doi/abs/10.1021/jo962132\%2B

2. Rudi, A.; Golderg, I.; Stein, Z.; Frolow, F.; Benayahu, Y.; Schleyer, M.; Kashman, Y. J. Org. Chem. 1994, 59, 999. (Isolation) http://pubs.acs.org/doi/abs/10.1021/jo00084a015

3. Terpin, A.; Polborn, K.; Steglich, W. Tetrahedron 1995, 51, 9941. (Synthesis of polycitrin A) http://www.sciencedirect.com/science/article/pii/004040209500568S

4. Becalli, E. M.; Clerici, F.; Marchesini, A. Tetrahedron 2000, 56, 2699. (Synthesis of polycitrin B)

http://www.sciencedirect.com/science/article/pii/S004040200000168X

5. Palermo, J. A.; Brasco, M. F. R.; Seldes, A. M. Tetrahedron 1996, 52, 2727. (Isolation) http://www.sciencedirect.com/science/article/pii/0040402096000099

6. Ebel, H.; Terpin, A.; Steglich, W. Tetrahedron Lett. 1998, 39, 9165. (Synthesis of permethylstorniamide A) http://www.sciencedirect.com/science/article/pii/S0040403998021339

7. Bowden, B. F. in Studies in Natural Products Chemistry; Rahman, A., Ed.; Elsevier Science: New York, 2000; Vol. 23, pp 233-283.

8. Gottesman, M. M.; Pastan, I. Ann. Rev. Pharmacol. Toxicol. 1999, 39, 361. http://www.annualreviews.org/doi/pdf/10.1146/annurev.pharmtox.39.1.361

9. Soenen, D. R.; Hwang, I.; Hedrick, M. P.; Boger, D. L. Bioorg. Med. Chem. Lett. 2003, 13, 1777. http://www.sciencedirect.com/science/article/pii/S0960894X03002944

10. Tao, H.; Hwang, I.; Boger, D. L. Bioorg. Med. Chem. Lett. 2004, 14, 5979. http://www.sciencedirect.com/science/article/pii/S0960894X04012259

11. MDR is the acronym for multidrug resistance.

12. Peschko, C.; Steglich, W. Tetrahedron Lett. 2000, 41, 9477. http://www.sciencedirect.com/science/article/pii/S0040403900016142

13. Namsa-aid, A.; Ruchirawat, S. Org. Lett. 2002, 4, 2633. http://pubs.acs.org/doi/abs/10.1021/o1026074s 
14. Kuttruff, C. A.; Eastgate, M. D.; Baran, P. S. Nat. Prod. Rep. 2014, 31, 419. http://pubs.rsc.org/en/content/articlelanding/2014/np/c3np70090a\#!divAbstract

15. Newhouse, T.; Baran, P. S.; Hoffmann, R. W. Chem. Soc. Rev. 2009, 39, 3010. http://pubs.rsc.org/en/content/articlelanding/2009/cs/b821200g\#!divAbstract

16. Trost, B. M. Acc. Chem. Res., 2002, 35, 695.

http://pubs.acs.org/doi/abs/10.1021/ar010068z 